\title{
2-Cyanoethylzinc Iodide: A New Reagent with Reactivity Umpolung
}

\author{
Ming Chang P. Yeh and Paul Knochel*
}

Department of Chemistry, The University of Michigan, Ann Arbor, Michigan 48109

Summary: 2-Cyanoethylzinc iodide 1 generated in over 90\% yield from 3-iodopropionitrile and zinc in THF can be transmetallated to the copper and titanium derivatives 3 and 4 which react in good yields, respectively, with acyl chlorides, enones, allylic halides and benzaldehyde.

Several functionalized zinc organometallics containing a halide, ${ }^{1}$ an ester- $, 2,3$ a cyano- ${ }^{3}$ or even a ketone- $-3,4$ group have been reported and used to form new carbon-carbon bonds. We have recently found that various polyfunctional alkyl iodides can be converted into the corresponding zinc derivatives in high yields ${ }^{3}$ by using zinc (activated with $4 \%$ of 1,3-dibromoethane and 3\% chlorotrimethylsilane) in THF under very mild conditions $\left(25^{\circ} \mathrm{C}\right.$ for secondary iodides, $25-40^{\circ} \mathrm{C}$ for primary iodides). These zinc iodides could be transmetallated into copper compounds of the new ${ }^{3}$ type $\mathrm{RCu}(\mathrm{CN}) \mathrm{ZnI}$ by using the soluble copper salt $\mathrm{CuCN} \cdot 2 \mathrm{LiX}(\mathrm{X}=\mathrm{Br}, \mathrm{Cl})$. We now report that our method allows the generation of 2-cyanoethylzinc iodide 1 from 3-iodopropionitrile $2^{5}$ and zinc in THF at $25^{\circ} \mathrm{C}$ in over $90 \%$ yield. Compound 1 could then be transmetallated ${ }^{3}$ with $\mathrm{CuCN} \cdot 2 \mathrm{LiCl}$ and $\mathrm{Cl}_{2} \mathrm{Ti}(\mathrm{Oi}-\mathrm{Pr})_{2}{ }^{6}$ into the copper and titanium organometallics tentatively represented by 3 and 4 , respectively (see Scheme 1). These new $d^{3}$-reagents 7
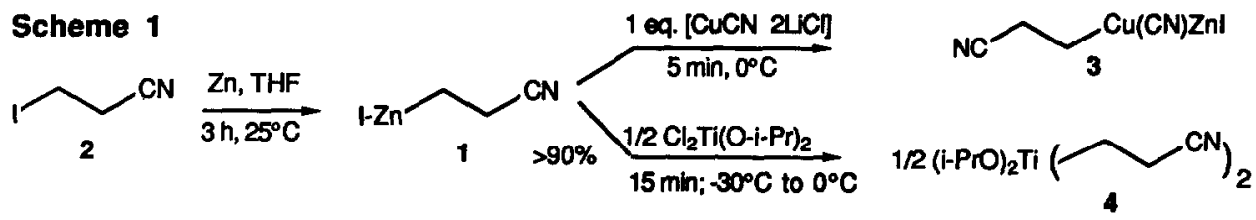

react readily with various organic electrophiles. Thus, the addition of acyl chlorides $\left(0.8 \mathrm{eq} . ; 0^{\circ} \mathrm{C} ; 2 \mathrm{~h}\right)$ to the copper compound 3 afforded the $\beta$-cyano ketones 5-7 in 77-83\% yield (see Scheme 2). By the reaction of 3 with enones $\left(0.8 \mathrm{eq} . ;-78^{\circ} \mathrm{C}\right.$ to $\left.25^{\circ} \mathrm{C}\right)$ in the presence of chlorotrimethylsilane 8 (2 eq.), the 1,4 -addition products $8-10$ are obtained in satisfactory yields (65-95\%; see Scheme 2$)$. Allylic halides ( $0.8 \mathrm{eq}$.) react with 3 and furnish the allylated products 11-14 $\left(0^{\circ} \mathrm{C} ; 2.5 \mathrm{~h} ; 83-99 \%\right)$. This reaction proceeds regiospecifically ${ }^{9}$ and cinnamyl bromide and 3-chloro-1-butene afford only the $S_{\mathrm{N}} 2$ products 13 and 14 . The $S_{\mathrm{N}} 2$ substitution product 15 can also be obtained regiospecifically by directly treating the zinc reagent 1 with cinnamyl bromide (0.8 eq.) in the presence of $1 \mathrm{~mol} \%$ of Pd(PPh3) $(12 \mathrm{~h}$; $45^{\circ} \mathrm{C} ; 68 \%$ ). Finally, while reaction of 1 with aldehydes is very sluggish, the titanium reagent 4 (1.5 eq.) reacts with benzaldehyde to furnish the addition product $16\left(0^{\circ} \mathrm{C}, 3 \mathrm{~h} ; 25^{\circ} \mathrm{C}, 3 \mathrm{~h} ; 81 \%\right)$.

Further synthetic applications of substituted derivatives of 1 as well as the determination of the X-ray structure of 1 are currently underway in our laboratory. 
<smiles>CC(C)(CCC#N)c1ccccc1</smiles>

5: $83 \%$ from $\mathrm{PhCOCl}$<smiles>CC(C)(CCC#N)C1CCC(=O)C1</smiles>

9: $65 \%$ from cyclopentenone
Scheme $2^{\circ}$<smiles>CC(C)(CCC#N)C(=O)CCCCl</smiles>

6: $77 \%$ from $\mathrm{Cl}_{(}\left(\mathrm{CH}_{2}\right)_{3} \mathrm{COCl}$<smiles>CC(=O)CC(C)(CCC#N)C(C)c1ccccc1</smiles>

10: $95 \%$ from benzalacetone<smiles>CC(C)(CCC#N)C(=O)C1CCCCC1</smiles>

7: $79 \%$ from $c-\mathrm{C}_{6} \mathrm{H}_{11} \mathrm{COCl}$<smiles>C=C1COC(=O)C(C)(CCC#N)C1</smiles>

11 : $99 \%$ from t-butyl $\alpha$-(bromomethyl)acrylate<smiles>CC(C)(CCC#N)C1CCCC(=O)C1</smiles>

8: $86 \%$ from cyclohexenone<smiles></smiles>

12: $83 \%$ from 3-chloro2-chloromethyl1-propene<smiles>CC(C)(CCC#N)c1ccccc1</smiles>

16: $81 \%$ from $\mathrm{PhCHO}$
13: $92 \%$ from cinnamyl bromide

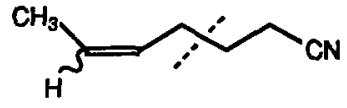

14: $84 \%$ from 3-chloro-1-butene (cis/trans mixture)<smiles>CC(C)(CC=Cc1ccccc1)CCC#N</smiles>

15: $68 \%$ from cinnamyl bromide

${ }^{a}$ All indicated yields are isolated yields. Satisfactory spectral data (IR, ${ }^{1} \mathrm{H}$ and ${ }^{13} \mathrm{C}-\mathrm{NMR}$, mass spectra) and elemental analysis were obtained for all new compounds. The newly formed bonds are indicated by dotted lines.

Acknowledement: We thank the Chemistry Department of the University of Michigan for support of this work.

\section{References}

1. Comins, D. L.; O'Connor, S. Tetrahedron Lett. 1987, 28, 1843.

2. (a) Tamaru, Y.; Ochiai, H.; Nakamura, T.; Tsubaki, K.; Yoshida, Z. Tetrahedron Lett. 1985, 26, 5559. (b) Tamaru, Y.; Ochiai, H.; Nakamura, T.; Yoshida, Z. Tetrahedron Lett. 1986, 27, 955. (c) Nakamura, E.; Sekiya, K.; Kuwajima, I. Tetrahedron Lett. 1987, 28, 337. (d) El Alami, N.; Belaud, C.; Villieras, J. L Organomet. Chem. 1987, 319, 303.

3. Knochel, P.; Yeh, M. C. P.; Berk, S. C.; Talbert, J. J. Org. Chem. 1988, submitted for publication.

4. Tamaru, Y.; Ochiai, H.; Nakamura, T.; Yoshida, Z. Angew. Chem. 1987, 99, 1193.

5. 3-Iodopropionitrile was prepared from the commercially available chloride (1.5 eq. of NaI in acetone; $15 \mathrm{~h}$ reflux; 78\%).

6. (a) Reetz, M. P. Pure Appl. Chem. 1985, 1781. (b) Weidmann, B.; Seebach, D. Angew, Chem. 1983, 25 , 12.

7. For a definition of the $\mathrm{a}^{\mathrm{n}} / \mathrm{d}^{\mathrm{n}}$ nomenclature, see: Seebach, D. Angew. Chem. 1979, $21,259$.

8. (a) Corey, E. J.; Boaz, N. W. Tetrahedron Lett. 1985, 26, 6015, 6019. (b) Alexakis, A.; Berlan, J.; Besace, Y. Tetrahedron Lett. 1986, 27, 1047. (c) Horiguchi, Y.; Matsuzawa, S.; Nakamura, E.; Kuwajima, I. Tetrahedron Lett. 1986, 27, 4025. (d) Nakamura, E.; Matsuzawa, S.; Horiguchi, Y.; Kuwajima, I. Tetrahedron Lett. 1986, $27,4029$.

9. $\mathrm{R}_{2} \mathrm{Zn}$ in the presence of $\mathrm{CuBr} \cdot \mathrm{Me} \mathrm{C}_{2} \mathrm{~S}$ has been reported to give very high $\mathrm{S}_{\mathrm{N}} 2 / \mathrm{S}_{\mathrm{N}} 2$ product ratios: Nakamura, E.; Aoki, S.; Sekiya, K.; Oshino, H.; Kuwajima, I. L.Am. Chem. Soc. 1987, $109,8056$. 